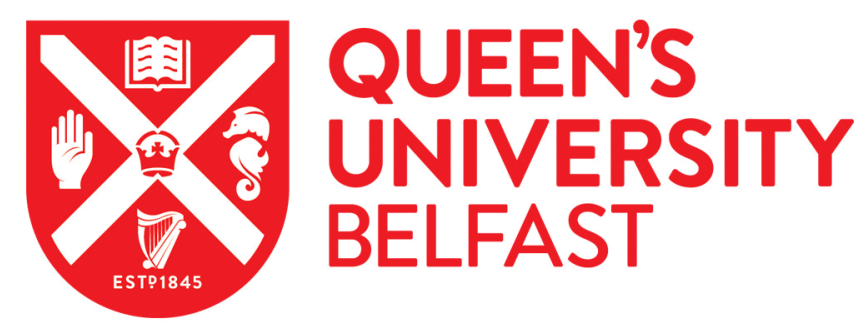

\title{
A qPCR MGB probe based eDNA assay for European freshwater pearl mussel (Margaritifera margaritifera L.)
}

Carlsson, J. E. L., Egan, D., Collins, P. C., Farrell, E. D., Igoe, F., \& Carlsson, J. (2017). A qPCR MGB probe based eDNA assay for European freshwater pearl mussel (Margaritifera margaritifera L.). Aquatic Conservation Marine and Freshwater Ecosystems. https://doi.org/10.1002/aqc.2788

Published in:

Aquatic Conservation Marine and Freshwater Ecosystems

Document Version:

Peer reviewed version

Queen's University Belfast - Research Portal:

Link to publication record in Queen's University Belfast Research Portal

Publisher rights

Copyright $\odot 2017$ John Wiley \& Sons, Ltd. This work is made available online in accordance with the publisher's policies. Please refer to any applicable terms of use of the publisher.

\section{General rights}

Copyright for the publications made accessible via the Queen's University Belfast Research Portal is retained by the author(s) and / or other copyright owners and it is a condition of accessing these publications that users recognise and abide by the legal requirements associated with these rights.

Take down policy

The Research Portal is Queen's institutional repository that provides access to Queen's research output. Every effort has been made to ensure that content in the Research Portal does not infringe any person's rights, or applicable UK laws. If you discover content in the Research Portal that you believe breaches copyright or violates any law, please contact openaccess@qub.ac.uk. 
Jeanette E.L. Carlsson ${ }^{1}$, Patrick C. Collins ${ }^{1,2}$, Edward D Farrell ${ }^{1}$, Damian Egan ${ }^{3}$, Fran Igoe $^{4}$ \& Jens Carlsson ${ }^{1}$ 2

3 A qPCR MGB probe based eDNA assay for freshwater pearl mussel (Margaritifera margaritifera L.) in an Irish 4 River

5

$6 \quad{ }^{1}$ Area 52 Research Group, School of Biology \& Environmental Science/Earth Institute,

7 University College Dublin, Belfield, Dublin 4, Ireland.

8

${ }^{2}$ Queen's University Marine Laboratory (QML), 12-13 The Strand, Portaferry, Co. Down, Northern Ireland, BT221PF UK.

11

$12{ }^{3}$ School of Biology \& Environmental Science, University College Dublin, Belfield, Dublin 4, Ireland.

13

Corresponding Author:

Email: nettan11@gmail.com, jeanette.carlsson@ucd.ie,

Telephone: +353 (01) 7162395

\section{Abstract 250 words}

Keywords 4 - 6 Conservation, Detection, Ireland, Quantitative PCR

Introduction $\max 2000$ words

Freshwater pearl mussel Margaritifera margaritifera L, are large $(\sim 14 \mathrm{~cm})$, long lived ( $>100$ years) bivalves 
Within Western Europe, this has precipitated protection and conservation actions under national and international legislation including the listing of M. margaritifera under Annex II and V of the Habitats Directive (92:43: EEC). This has ensured that many rivers with M. Margaritifera sub populations have been designated as Special Areas of Conservation (SAC). The species is further protected under national legislation and is legally protected in Ireland under Schedule 1 of the Wildlife Act (Protection of Wild Animals) (Statutory Instrument

No. 112, 1990) and the European Communities (Natural Habitats) Regulations (Statutory Instrument No. 94, 1997)

Although recent estimates have suggested a total 1282 sub populations, this is expected to be reduced to 204 sub populations by 2100 . The island of Ireland currently supports 139 sub populations, with an expected number of subpopulations being reduced to 6 by 2100 (Mookhens et al., 2011). However, currently the species is still widespread in Ireland, although abundances have declined (Geist 2005). These subpopulations may provide a potential source for re-colonisation, given proposed improvements in future water and habitat quality-levels as outlined under the European Water Framework.

There is a recognised linkage between healthy stocks of salmonids such as brown trout (Salmo trutta L.) and

Atlantic salmon (S. salar L.) and the endurance, growth and propagation and of M. margaritifera sub populations (Bauer 1979; Ziuganov and Nezlin 1988; Ziuganov et al. 1994). Studies have suggested a symbiotic releationship between salmonids and M. margaritifera - the mussels maintain water quality required by the salmonids and have been shown to reduce senility in salmon, thereby extending their life expectancy (Ziuganov 2005!). The salmonids gills host M. margaritifera glochidium, a larval stage of $M$. margaritifera that requires salmonids for dispersal. The chances of a glochidium successfully finding a host in waters with healthy salmonid stocks is as low as $0.0004 \%$, with only $5 \%$ of these successfully attaching which can only survive for (Young and Williams 1984;). The pearl mussels have evolved to live in ultra- oligotrophic waters, where obligate salmonid host populations (e.g. brown trout) were never high and depend on the anadromous sea trout 
61 the successful attachment of glochidium and by extension recruitment and population viability of $M$. margaritifera (Bauer 1979). Therefore, any recovery M. margaritifera populations is dependent on and concomitant with the promotion of healthy salmonid populations. As an added value, the presence of $M$. margaritifera beds aids the legal designation and maintenance of high quality salmonid nursery habitats for through complementary legal protection.

66 M. margaritifera are important members of the food web in soft-water nutrient poor ecosystems; transferring nutrients and energy from the water column to the sediments through filter feeding, stimulating production across trophic levels (Spooner and Vaughn 2006). A previous study (Stoeckle et al. 2015) developed $M$. margaritifera specific primers anchored in 16S mitochondrial (mt)DNA region and successfully deployed the assay on environmental (e)DNA samples from Central Europe. However, while 16S sequences from different organisms are abundant in public repositories, it would be advantageous to focus on the barcode of life gene (mtDNA COI - http://www.barcodeoflife.org) as repositories of COI sequences contain representatives from many more organisms than any other gene sequence repository. Further improvements of eDNA assays include adding species specific probes with higher fidelity (e.g. minor grove binding, MGB probes) than both assays based solely on species specific primers or those also incorporating TaqMan® probes not using the MGB group (Kutyavin et al. 2000).

The aim of the current study was to develop an eDNA assay that can detect the presence and relative

abundances of M. margaritifera without hard sampling. This approach may allow for the detection of previously unrecorded populations that would require recognition and a measure of protection. Remnant populations may exist at densities too low for observation by traditional studies; acting as a potential source of recruits for repopulation. The approach would also allow for the identification of $M$. margaritifera hotspots; zones that support relatively a larger proportion of the mussel population. 
All DNA tissue originated from a naturally diseased individual M. margaritifera. Found on the bank of the River Munster Blackwater (Fran Igoe personal comments). The tissue sample was received and total DNA was extracted from these tissue samples using the Qiagen Dneasy kit (Qiagen, Valencia, CA). Extracted DNA was used as template for assay validation and standard curves for qPCR. Species-specific primers for $M$. margaritifera (forward primer: 5'- TTG TTG ATT CGT GCT GAG TTA GG-3', and reverse primer: 5'- GCA TGA GCC GTA ACA ATA ACA TTG-3') and 5'-6-FAM labelled TaqMan ${ }^{\circledR}$ minor groove binding probe (5'CCT GGT TCT TTG CTG GGT-3') targeting region within the mtDNA cytochrome oxidase I (COI) region were designed using PRIMER EXPRESS 3.0 (Applied Biosystems-Roche, Branchburg, NJ). The total amplicon size, including primers, was $83 \mathrm{bp}$. Probe and primer sequences were matched against the National Centre for Biotechnology Information (NCBI - http://www.ncbi.nlm.nih.gov/) nucleotide database with BLASTn (Basic Local Alignment Search Tool) to confirm the species specificity for M. margaritifera in in-silico assays. The specificity and amplification capability of the assay was confirmed by conventional PCR amplification and DNA visualisation on a $1.5 \%$ agarose gel stained with SYBR ${ }^{\circledR}$ Safe - DNA Gel Stain (Life Technologies). In addition, to the qPCR eDNA assay for M. margaritifera, we included a previously developed eDNA qPCR assay (Gustavson et al. 2015) for brown trout (S. trutta) as a positive control for presence of amplifiable eDNA in water samples. amount of water filtered was recorded for each water sample to the closest cL. Filters were subsequently dehydrated with $100 \%$ EtOH before storage at $-20^{\circ} \mathrm{C}$. Each filter was cut into halves (half for analysis and half for archival storage) and shredded to increase surface area for eDNA extraction using Qiagen QIAshredder (Qiagen, Valencia, CA). Total eDNA was extracted using a Qiagen DNeasy kit (Qiagen, Valencia, CA). Extracted eDNA was stored at $-20^{\circ} \mathrm{C}$ until further processing.

\section{eDNA assay deployment} Concentrations of eDNA were determined by qPCR using an Applied Biosystems ViiA ${ }^{\mathrm{TM}} 7$ (Life Technologies, 
included: $15 \mu$ l of TaqMan ${ }^{\circledR}$ Environmental Master Mix 2.0 (Life Technologies., Applied Biosystems, Foster City, CA), $3 \mu 1$ of each primers (final concentration of $0.2 \mu \mathrm{M}$ ), probe (final concentration of $0.2 \mu \mathrm{M}$ ), ddH2O, and DNA template $(3 \mu \mathrm{l})$, forming the $30 \mu \mathrm{L}$ reaction volume. The $\mathrm{qPCR}$ run method used warm-up conditions of $50^{\circ} \mathrm{C}$ for $2 \mathrm{~min}$ and $95^{\circ} \mathrm{C}$ for $10 \mathrm{~min}$, followed by 40 cycles between $95^{\circ} \mathrm{C}$ for $15 \mathrm{~s}$ and $60^{\circ} \mathrm{C}$ for $1 \mathrm{~min}$. The standard curve for M. margaritifera was generated with quantified (NanoDrop ${ }^{\circledR}-1000$, Thermo Scientific, Wilmington, DE) DNA extractions from a tissue sample (DNA concentrations of 122.0 pg/L) using seven 10:1 serial dilutions as template for $\mathrm{qPCR}$. The standard curve for M. margaritifera $\left(\mathrm{y}=-3.4058 \mathrm{x}+38.238, \mathrm{R}^{2}=\right.$ 0.9997, efficiency $=96.62 \%$ ) was generated using $3 \mu 1$ DNA template in a total reaction volume of $30 \mu 1$, respectively. The lowest concentrations of DNA (dynamic range) equalling $0.122 \mathrm{pg} / \mathrm{L}$ in the standard curves were detected at $\mathrm{Cq}$ (quantification cycle) 34.8 (average over three technical replicates, $\mathrm{SD}=0.073$ ). Results from the standard curve (Fig. 1.) indicate a dynamic range and lowest eDNA detection level at Cq 38.238 (equivalent to a M. margaritifera DNA concentration of $0.333 \mathrm{pg} / \mathrm{L}$ ). All field samples were quantified in duplicates (two technical replicates), to ensure consistency, with two laboratory negative controls and $M$. margaritifera. Three water samples within the Munster Blackwater River system were used as template for $S$. trutta qPCR to validate the presence of amplifiable eDNA. The average $\mathrm{Cq}$ across technical replicates $(\mathrm{n}=2)$ were used for quantification.

\section{Results and Discussion}

The present study successfully developed an eDNA assay with very high sensitivity for M. margaritifera. All analysed samples yielded detectable eDNA (with Cq within the dynamic range) for both M. margaritifera and $S$. trutta (presence of $S$. trutta eDNA was validated in three sample locations), indicating that amplifiable target eDNA was present in all water samples. Resulting $\mathrm{Cq}$ values from the $\mathrm{qPCR}$ assays were transformed to $\mathrm{pgDNA} / \mathrm{L}$ (based on the standard curve, Fig 1.). The concentrations of eDNA ranged from $0.462 \mathrm{pg} / \mathrm{L}$ in Rowls Aldworth West Bridge (right bank sample) to the highest of $109.884 \mathrm{pg} / \mathrm{L}$ in the Leader's Bridge Allow (left bank sample). Environmental DNA concentrations were relatively stable across transects within location (right bank, middle and left bank samples). Average eDNA concentrations (across transects) ranged from the lowest at in Rowls Aldworth West Bridge (1.056 pg/L) to the highest at Cullen Bridge (79.412 pg/L). Two graphs were plotted to visualise eDNA concentrations (Figs. 2 and 3). These results indicate variable eDNA concentrations among localities. The developed eDNA assay can be used to assess concentrations of eDNA which should be

Commented [JC1]: What do we do here. We do not need to have tons of locations. Just one field sample and one negative field sample... 
related to the biomass of M. margaritifera and could be used for monitoring the status of M. margaritifera in individual locations and river systems. However, utilising the quantifying capabilities of eDNA assays requires careful planning, standardised and coordinated sampling efforts (exact GPS positions, dates, time of day, water levels, weather conditions, details about where in the water body samples were acquired from, etc.) to ensure that samples are of the highest quality. Nevertheless, the eDNA assay developed here can be used for rapid detection of M. margaritifera presence throughout Ireland and the natural range of M. margaritifera. Wide scale deployment of the assay can help detecting cryptic populations in watersheds where M. margaritifera has not previously been reported or where $M$. margaritifera are considered to have gone extinct. unreported, unviable subpopulations of M. Margaritifera in suboptimal habitats to either recently refurbished or pre-existing optimal habitats (clean water and salmonids). This will ensure gene transfer between sub populations and maintain genetic diversity in existing sub populations. The transferral of genetic material is pertinent given the additional stresses of climate change. Unfortunately, given the low levels of funding and political priority for conservation, this approach requires a hierarchical valuation of M. margaritifera habitats and the focusing of efforts on SAC designated viable habitats.

\section{Acknowledgements}

This project was supported The LEADER programme 2007-2014. P.C.C and J.C acknowledge funding from

Science Foundation Ireland (SFI 12/IP/1308). The authors acknowledge Nuala Riordan, IRD Duhallow and transport of samples. 
Conflict of Interest: The authors declare that they have no conflict of interest. 


\section{References MAX 30}

Moorkens EA (1999) Conservation management of the freshwater pearl mussel Margaritifera margaritifera. Part

1: Biology of the species and its present situation in Ireland. Irish Wildlife Manuals, 8, 4-31.

Bauer G (1979) Untersuchungen zur Fortpflanzungsbiologie der Flußperlmuschel im Fichtelgebirge. Arch Hydrobiol 98: 523-532.

Bauer G (1986) The status of the freshwater pearl mussel Margaritifera margaritifera L. in the south of its European range. Biol Cons 38: 1-9.

Bauer G (1992) Variation in life span and size of the freshwater pearl mussel. J Anim Ecol 61: 425-436. Stoeckle BC, Kuehn R, Geist J (2015) Environmental DNA as a monitoring tool for the endangered freshwater pearl mussel (Margaritifera margaritifera L.): a substitute for classical monitoring approaches? Aquat Conserv DOI: $10.1002 / \mathrm{aqc} .2611$.

Geist J (2005) Conservation genetics and ecology of European freshwater pearl mussels (Margaritifera margaritifera L.). Dissertation, Technischen Universität München.

Gustavson MS, Collins PC, Finarelli JA, Egan D, Conchúir RÓ, Wightman GD, King JJ, Gauthier DT, Whelan K, Carlsson JEL, Carlsson J (2015) An eDNA assay for Irish Petromyzon marinus and Salmo trutta and field validation in running water. J Fish Biol 87: 1254-1262.

IUCN (International Union for the Conservation of Nature) (1991) Invertebrate red list. IUCN, Gland, Switzerland.

Kutyavin IV, Afonina IA, Mills A, Gorn VV, Lukhtanov EA, Belousov ES, Singer MJ, Walburger DK, Lokhov SG, Gall AA, Dempcy R (2000). 3'-minor groove binder-DNA probes increase sequence specificity at PCR extension temperatures. Nucleic Acids Res 28: 655-661.

Young MR, Cosgrove PJ, Hastie LC (2001) The extent of, and causes for, the decline of a highly threatened naiad: Margaritifera margaritifera. In: Bower G and Wachtler K (eds) Ecology and Evolution of the Freshwater Mussels Unionoida. Ecological Studies, no. 145. Springer-Verleg, Berlin, pp 337-357.

Spooner DE, Vaughn CC (2006) Context-dependent effects of freshwater mussels on stream benthic communities. Freshwater Biol 51: 1016-1024

Young MR, Williams JC (1984) The reproductive biology of the freshwater pearl mussel Margaritifera margaritifera (Linn.) in Scotland. I. Field studies. Arch Hydrobiol 99: 405-422. 


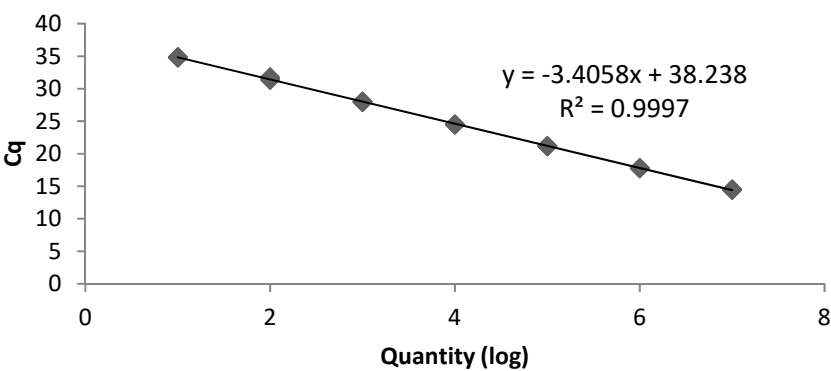

Fig. 1. Standard curve used to quantify Margaritifera margaritifera eDNA concentrations. This curve is based on known concentrations and dilution series (10X) from a starting concentration of 0.122pg/L, Cq - quantification cycle.

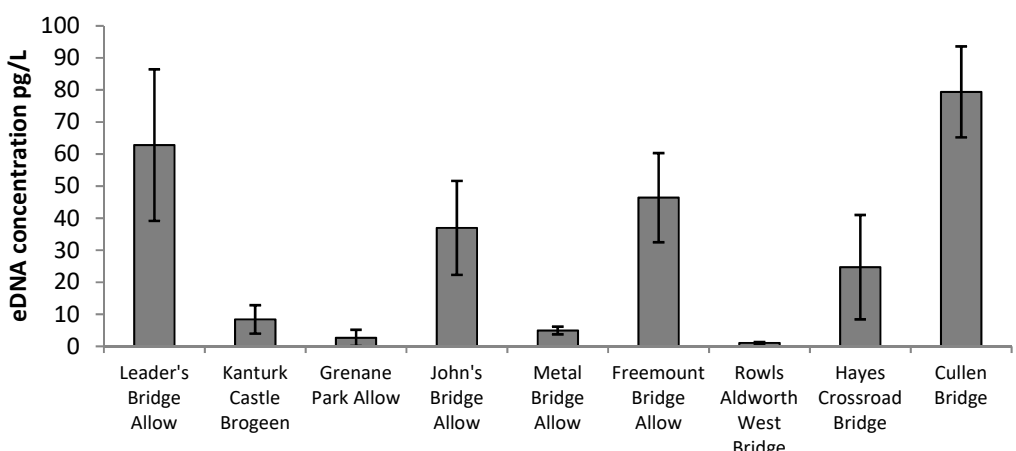

Fig. 2. Average concentrations (error bars indicate 95\% C.I within locations) of Margaritifera margaritifera eDNA among water samples from the Munster Blackwater river system.

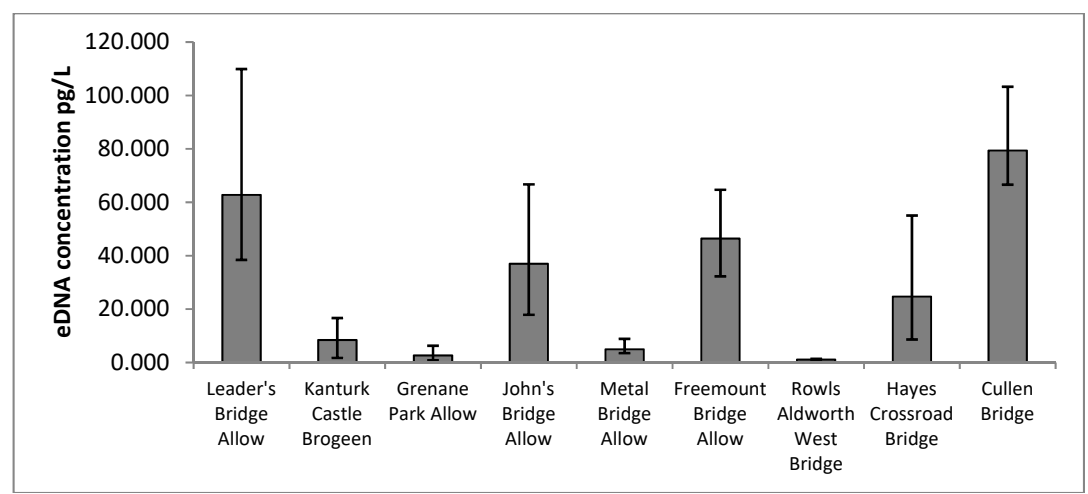


221 Fig. 3. Average concentrations (error bars indicate observed max and min eDNA concentrations within

222 locations) of Margaritifera margaritifera eDNA among water samples from the Munster Blackwater river system. 

river system. (loc - location number, site $L$ - left bank sample, site $M$ - mid river sample, site $R$ - right bank sample, Cq-quantification cycle, T1 - technical replicate 1, T2 - technical replicate 2).

\begin{tabular}{|c|c|c|c|c|c|c|c|}
\hline Location name & Loc & site & CqT1 & $\mathrm{CqT2}$ & $\begin{array}{l}\text { Average } \\
\mathrm{Cq}\end{array}$ & $\begin{array}{l}\text { Average eDNA } \\
\text { Conc across } \\
\text { technical } \\
\text { replicates pg/Ll }\end{array}$ & $\begin{array}{l}\text { Average } \\
\text { eDNA Conc } \\
\text { across } \\
\text { location } \\
\text { pg/L }\end{array}$ \\
\hline \multicolumn{8}{|l|}{ Leader's Bridge } \\
\hline \multirow[t]{3}{*}{ Allow } & 1 & $\mathrm{~L}$ & 29.662 & 30.049 & 29.8555 & 96.410 & 62.796 \\
\hline & & M & 30.796 & 30.786 & 30.791 & 51.220 & \\
\hline & & $\mathrm{R}$ & 31.216 & 31.042 & 31.129 & 40.757 & \\
\hline \multicolumn{8}{|l|}{ Kanturk Castle } \\
\hline \multirow[t]{3}{*}{ Brogeen } & 2 & $\mathrm{~L}$ & 35.053 & 34.082 & 34.5675 & 7.973 & 8.405 \\
\hline & & M & 36.844 & 35.107 & 35.9755 & 3.078 & \\
\hline & & $\mathrm{R}$ & 33.478 & 33.957 & 33.7175 & 14.165 & \\
\hline \multirow[t]{3}{*}{ Grenane Park Allow } & 4 & $\mathrm{~L}$ & 37.733 & 37.176 & 37.4545 & 1.132 & 2.660 \\
\hline & & M & 37.856 & N/A & 37.856 & 0.863 & \\
\hline & & $\mathrm{R}$ & 34.924 & 35.06 & 34.992 & 5.984 & \\
\hline \multirow[t]{3}{*}{ John's Bridge Allow } & 7 & $\mathrm{~L}$ & 32.672 & 33.373 & 33.0225 & 22.660 & 36.946 \\
\hline & & M & 32.806 & 32.355 & 32.5805 & 30.552 & \\
\hline & & $\mathrm{R}$ & 31.426 & 31.858 & 31.642 & 57.624 & \\
\hline \multirow[t]{3}{*}{ Metal Bridge Allow } & 8 & $\mathrm{~L}$ & 35.783 & 35.661 & 35.722 & 3.653 & 4.941 \\
\hline & & M & 34.412 & 35.289 & 34.8505 & 6.585 & \\
\hline & & $\mathrm{R}$ & 35.77 & 35.002 & 35.386 & 4.585 & \\
\hline \multicolumn{8}{|l|}{ Freemount Bridge } \\
\hline \multirow[t]{3}{*}{ Allow } & 9 & $\mathrm{R}$ & 31.772 & 31.471 & 31.6215 & 58.428 & 46.389 \\
\hline & & M & 32.498 & 32.361 & 32.4295 & 33.836 & \\
\hline & & $\mathrm{L}$ & 31.841 & 32.052 & 31.9465 & 46.903 & \\
\hline \multicolumn{8}{|l|}{ Rowls Aldworth } \\
\hline \multirow{2}{*}{ West Bridge } & & M & 37.233 & N/A & 37.233 & 1.315 & \\
\hline & & $\mathrm{R}$ & 38.779 & 37.166 & 37.9725 & 0.798 & \\
\hline \multicolumn{7}{|l|}{ Hayes Crossroad } & 24.708 \\
\hline \multirow{2}{*}{ Bridge } & & M & 34.458 & 34.378 & 34.418 & 8.821 & \\
\hline & & $\mathrm{L}$ & 32.133 & 31.711 & 31.922 & 47.686 & \\
\hline \multirow[t]{3}{*}{ Cullen Bridge } & 16 & $\mathrm{R}$ & 30.779 & 30.881 & 30.83 & 99.775 & 79.412 \\
\hline & & M & 31.304 & 31.367 & 31.3355 & 70.892 & \\
\hline & & $\mathrm{L}$ & 31.385 & 31.428 & 31.4065 & 67.570 & \\
\hline
\end{tabular}

